\title{
Persepsi Dan Kecenderungan Siswa SMA Dalam Memilih Pendidikan Tinggi Lanjutan Di Masa Pandemi Covid 19
}

Studi Empiris Pada Siswa SMA Negeri 1 Blangjerango Kabupaten Gayo Lues

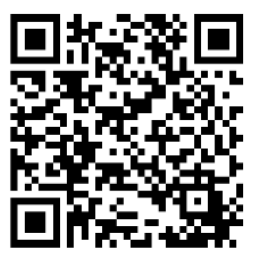

Fajar Okta Widarta1 ${ }^{1}$ Ikhsan 1 , Bambang²

DOl: https://doi.org/10.36339/jaspt.v5i1.402

\begin{abstract}
This study aims to determine the effect of students' perceptions on higher education and their tendency to choose further higher education. This is a quantitative descriptive research, with the research population being 171 students of SMA Negeri 1 Blangjerango in the academic year 2020/2021. Random sampling technique is used in sampling. Data collection using a questionnaire with a Likert scale. Data analysis using descriptive statistical analysis. The results of data analysis showed that: (1) students' perceptions of higher education and their tendency to choose further higher education were in the very good category (85.57\%); (2) there is a significant positive effect on students' perceptions of higher education on the tendency to choose further higher education, with a large effect of $27.1 \%$.
\end{abstract}

Keywords: students of senior high school, perception, higher education.

\section{Abstrak}

Penelitian ini bertujuan untuk mengetahui pengaruh persepsi siswa terhadap pendidikan tinggi dan kecenderungan mereka dalam memilih pendidikan tinggi lanjutan. Jenis penelitian ini adalah deskriptif kuantitatif, dengan populasi penelitian adalah siswa SMA Negeri 1 Blangjerango tahun akademik 2020/2021 berjumlah 171 siswa. Teknik random sampling digunakan dalam pengambilan sampel. Pengumpulan data menggunakan angket dengan skala Likert. Analisis data menggunakan analisis statistik deskriptif. Hasil analisis data menunjukkan bahwa: (1) persepsi siswa terhadap pendidikan tinggi dan kecenderungan mereka memilih pendidikan tinggi lanjutan berada pada kategori sangat baik $(85,57 \%)$; (2) terdapat pengaruh positif yang signifikan persepsi siswa mengenai pendidikan tinggi terhadap kecenderungan memilih pendidikan tinggi lanjutan, dengan besar pengaruh sebanyak $27,1 \%$.

Kata Kunci: siswa sma, persepsi, pendidikan tinggi.

\section{PENDAHULUAN}

Tantangan kehidupan di masa yang akan datang demikian besarnya. Setiap orang dituntut memiliki kemampuan yang tinggi serta keahlian khusus agar dapat hidup layak dan mampu menyesuaikan diri dengan perubahan zaman. Sehingga mereka mampu bersaing dalam memperebutkan kesempatan kerja yang sangat terbatas dan memenuhi kebutuhan hidup sehari-hari. Hal tersebut cukup menjadi alasan mengapa saat ini

1. Program Studi Pendidikan Biologi PSDKU USK Gayo Lues, Indonesia

2. Program Studi Manajemen PSDKU Universitas Syiah Kuala Gayo Lues, Indonesia. Jalan BlangkejerenBlangpidie KM.20, Blangjerango, Gayo Lues, Provinsi Aceh INDONESIA

Email of Corresponding Author : fajaroktawidarta@unsyiah.ac.id

JAS-PT

JURNAL ANALSIS SISTEM PENDIDIKAN TINGGI ISSN 2580 - 5339 eISSN $2620-5718$

Volume 5 Nomor 1

JULI 2021

Hal $17-28$

DOSEN INDONESIA SEMESTA 
kebutuhan akan layanan pendidikan yang baik menjadi salah satu kebutuhan dasar masyarakat.

Cara paling rasional yang dapat ditempuh masyarakat untuk memiliki pengetahuan dan keterampilan yang baik adalah dengan menempuh pendidikan setinggi-tingginya. Layanan pendidikan tinggi disediakan oleh perguruan tinggi yang merupakan jenjang pendidikan lanjutan setelah pendidikan menengah (SMA/SMK/MA/MAK).

Sejumlah manfaat yang dapat diperoleh siswa bila melanjutkan studinya ke perguruan tinggi, diantaranya: (1) memiliki pengetahuan yang luas serta menguasai bidang keahlian tertentu; (2) memperbesar peluang atau kesempatan kerja; (3) memperluas jaringan atau rekanan; dan (4) mengubah pola pikir siswa menjadi lebih baik.

Kecenderungan siswa dalam memilih perguruan tinggi menunjukkan minat dan motivasinya dalam meraih cita-cita. Hal ini akan menjadi faktor pendorong untuk mereka terus belajar dengan giat agar dapat bersaing dengan siswa lainnya. Kecenderungan siswa dalam memilih pendidikan tinggi ditunjukkan dari adanya keinginan diri untuk melanjutkan studi ke perguruan tinggi, adanya dorongan baik dari orangtua maupun lingkungan sosial kemasyarakatan, adanya perhatian siswa dan orangtua tentang pendidikan tinggi yang akan dipilih, serta adanya harapan baik dari siswa maupun orangtua terhadap pendidikan tinggi tersebut.

Kecenderungan dalam memilih pendidikan tinggi tumbuh dari persepsi siswa dan orangtua mengenai pendidikan tinggi. Anggapan atau pengetahuan ini muncul dari hasil interaksi seseorang dengan lingkungan masyarakatnya. Bila masyarakat sekitar memiliki persepsi yang positif tentang suatu hal, maka hal tersebut akan dipandang baik dan positif untuk dilakukan.

Setidaknya ada tiga hal yang membentuk persepsi seseorang tentang suatu pendidikan tinggi, diantaranya: (1) pengetahuan tentang pentingnya pendidikan tinggi; (2) pengetahuan tentang manfaat pendidikan tinggi; dan (3) akses informasi tentang suatu pendidikan tinggi. Persepsi positif siswa terhadap pendidikan tinggi akan memotivasinya untuk giat belajar agar dapat lulus di perguruan tinggi idamannya tersebut (Widarta, 2020).

SMA Negeri 1 Blangjerango terdapat di Kecamatan Blangjerango, Kabupaten Gayo Lues. Setiap tahunnya tidak sampai $50 \%$ siswa lulusan sekolah tersebut melanjutkan studi ke perguruan tinggi (Wawancara, 2021). Ada sejumlah dugaan yang menyebabkan hal tersebut terjadi, diantaranya: (1) faktor ekonomi keluarga; (2) kondisi sosial budaya; dan (3) minimnya informasi tentang perguruan tinggi.

Data Badan Pusat Statistik Kabupaten Gayo Lues tahun 2020 menunjukkan bahwa terdapat 18,42 ribu (19,32\%) jumlah penduduk miskin di kabupaten yang dijuluki negeri seribu bukit ini. Angka tersebut lebih tinggi dari angka jumlah penduduk miskin di dua kabupaten tetangganya, yaitu Kabupaten Aceh Tenggara dan Kabupaten Aceh Tengah. Kabupaten Aceh Tenggara pada tahun yang sama memiliki 13,21\% penduduk miskin, sementara Kabupaten Aceh Tengah memiliki 15,08\% penduduk miskin. Persentase jumlah penduduk miskin di Kabupaten Gayo Lues tersebut juga berada di atas

JAS-PT

JURNAL ANALISIS SISTEM PENDIDIKAN TINGGI ISSN $2580-5339$ eISSN $2620-5718$ Volume 5 Nomor 1 JULI 2021 Hal $17-28$
Sebagian besar masyarakat Kabupaten Gayo Lues adalah petani. Mereka menggarap lahan sendiri maupun bekerja di lahan orang lain sebagai buruh tani. Faktor ekonomi sering kali menjadi halangan masyarakat menyekolahkan anak-anaknya ke perguruan tinggi. Padahal salah satu faktor penting yang dapat mendukung majunya suatu daerah adalah ketersediaan sumber daya manusia yang mumpuni. 
Kondisi sosial budaya juga memiliki andil pada rendahnya minat dan persentase siswa Iulusan SMA di Kabupaten Gayo Lues melanjutkan studi ke perguruan tinggi. Angka pernikahan pada usia yang relatif muda juga tinggi di daerah ini. Belum lagi anggapan bahwa perempuan tidak perlu mengenyam pendidikan tinggi juga masih sangat kental di kalangan masyarakat sekitar. Umumnya siswa laki-laki setelah lulus SMA langsung bekerja di kebun. Wanitanya juga langsung mencari pekerjaan atau menikah. Mereka merasa sudah cukup bila sudah dapat menghasilkan uang meski jumlahnya sedikit.

Pengetahuan siswa mengenai dunia pendidikan tinggi relatif rendah. Umumnya masyarakat memahami bahwa biaya melanjutkan studi ke perguruan tinggi sangat mahal. Pengetahuan masyarakat mengenai berbagai bantuan pendidikan yang tersedia seperti beasiswa masih sangat kurang.

Penelitian terkait persepsi siswa terhadap pendidikan tinggi yang telah dilakukan diantaranya Sari \& Iqbal (2021) yang meneliti tentang persepsi siswa difabel terhadap kelanjutan studi di perguruan tinggi. Penelitian mereka mengungkap fakta bahwa minat siswa difabel untuk melanjutkan studi ke perguruan tinggi sangat rendah $(21,1 \%)$. Hidayat (2016) meneliti tentang persepsi siswa SMA Kota Parepare tentang STAIN Parepare. Menggunakan metode angket mereka menemukan fakta bahwa sebagain besar siswa SMA di Kota Parepare tidak terlalu mengenal STAIN Parepare $(63,47 \%)$ dan $53,11 \%$ siswa mengira STAIN Parepare hanya membuka program studi agama saja. Penelitian mereka juga mengungkap program studi apa saja di STAIN Parepare yang menjadi favorit siswa.

Mustika, Linda \& Irfal (2019) melakukan penelitian di Jakarta Selatan untuk melihat persepsi siswa terhadap minat kuliah di perguruan tinggi pariwisata. Data yang dihimpun menggunakan kuesioner dari 100 responden mengungkap bahwa siswa SMK lebih berminat untuk berkuliah di perguruan tinggi pariwisata (53\%) dibandingkan siswa SMA yang hanya sebesar $47 \%$. Juga diketahui rendahnya hubungan persepsi terhadap minat siswa untuk berkuliah di perguruan tinggi pariwisata.

Irnawati (2019) melakukan penelitian persepsi siswa terhadap pendidikan tinggi dan kecenderungannya memilih pendidikan tinggi lanjutan di salah satu sekolah di Makassar. Hasil penelitiannya menunjukkan bahwa terdapat pengaruh positif yang signifikan antara persepsi terhadap pendidikan tinggi dan kecenderungan memilih pendidikan tinggi lanjutan.

Banyak penelitian telah dilakukan terkait persepsi siswa terhadap pendidikan tinggi, namun belum ada penelitian yang mengkaji persepsi siswa SMA di Kabupaten Gayo Lues dan kecenderungan mereka dalam memilih pendidikan tinggi lanjutan, sehingga penelitian ini perlu dilakukan. Implikasi hasil penelitian ini nantinya dapat dijadikan sebagai masukan untuk membuat program layanan bimbingan dan konseling di sekolah (Triyono \& Febriani, 2018).

\section{METODE PENELITIAN}

Penelitian dilaksanakan di SMA Negeri 1 Blangjerango Kabupaten Gayo Lues pada Bulan Februari 2021. Jenis penelitian adalah deskriptif kuantitatif, yang mengkaji persepsi siswa SMA Negeri 1 Blangjerango terhadap pendidikan tinggi dan kecenderungan mereka dalam memilih pendidikan tinggi lanjutan.

Populasi dalam penelitian ini adalah seluruh siswa SMA Negeri 1 Blangjerango tahun akademik 2020/2021 berjumlah 171 siswa. Arikunto (2006) menjelaskan bila populasi cukup besar, misalnya lebih dari 100, maka jumlah sampel yang dapat diambil 10-15\% atau $20-25 \%$, tergantung dari kemampuan peneliti dan homogenitas data. Maka

JAS-PT

JURNAL ANALISIS SISTEM PENDIDIKAN TINGG

ISSN $2580-5339$

eISSN $2620-5718$

Volume 5

Nomor 1

JULI 2021

Hal 17 - 28

DOSEN INDONESIA SEMESTA 
menggunakan teknik cluster random sampling, diambil sampel sebesar $20 \%$ dari total populasi, sehingga sampel berjumlah 34 siswa. Instrumen yang digunakan berupa angket yang disusun menggunakan skala Likert.

Data penelitian selanjutnya diolah menggunakan pengukuran data ordinal dengan bobot skor untuk setiap pilihan jawaban sebagai berikut

Tabel 1. Bobot skor setiap pilihan jawaban

\begin{tabular}{lcc}
\hline \multirow{2}{*}{ Pilihan Jawaban } & \multicolumn{2}{c}{ Skor untuk pernyataan } \\
\cline { 2 - 3 } & Positif & Negatif \\
\hline Sangat Setuju (SS) & 4 & 1 \\
Setuju (S) & 3 & 2 \\
Tidak Setuju (TS) & 2 & 3 \\
Sangat Tidak Setuju (STS) & 1 & 4 \\
\hline
\end{tabular}

Instrumen berupa angket disusun mengikuti langkah-langkah penyusunan instrumen yang baik, termasuk perumusan kisi-kisi sesuai indikator dan pengujian instrumen meliputi uji validitas dan reliabilitas instrumen. Pengumpulan data juga dilakukan menggunakan teknik dokumentasi untuk mendapatkan sejumlah data.

Adapun variabel dan indikator pada instrumen angket yang digunakan dalam penelitian ini adalah sebagai berikut

Tabel 2. Variabel dan indikator pada instrumen

\begin{tabular}{lll}
\hline \multicolumn{1}{c}{ Variabel } & \multicolumn{1}{c}{ Indikator } \\
\hline Persepsi siswa terhadap pendidikan & 1. Pentingnya pendidikan tinggi \\
tinggi & 2. Manfaat pendidikan tinggi \\
& 3. Informasi tentang pendidikan tinggi \\
\hline Kecenderungan memilih pendidikan & 1. Adanya keinginan \\
tinggi lanjutan & 2. Adanya dorongan \\
& 3. Adanya perhatian \\
& 4. Adanya harapan \\
\hline
\end{tabular}

Penelitian ini menggunakan teknik analisis statistik deskriptif. Meliputi persentase, menggunakan rumus dari Sugiyono (2010), berikut:

$P=\frac{F}{N} x 100 \%$

Keterangan:

$\mathrm{P} \quad$ : Persentase pilihan jawaban

$\mathrm{F} \quad$ : Frekuensi pilihan jawaban

$\mathrm{N} \quad$ : Jumlah responden

Tabel 3. Kriteria penilaian hasil persentase menurut Riduwan (2004)

JAS-PT

JURNAL ANALISIS SISTEM PENDIDIKAN TINGGI

ISSN $2580-5339$

eISSN $2620-5718$

Volume 5

Nomor 1

JULI 2021

Hal $17-28$

DOSEN INDONESIA SEMESTA

\begin{tabular}{cc}
\hline Rentang Nilai & Kriteria \\
\hline $81 \%-100 \%$ & Sangat Baik \\
$61 \%-80 \%$ & Baik \\
$41 \%-60 \%$ & Cukup \\
$21 \%-40 \%$ & Kurang Baik \\
$0 \%-20 \%$ & Tidak Baik
\end{tabular}

Analisis regresi linear sederhana, dengan interpretasi nilai r mengikuti Sugiyono (2010), sebagai berikut:

20 | JURNAL ANALISIS SISTEM PENDIDIKAN TINGGI | VOL. 5 NO. 1 2021, pp. 17-28 
Tabel 4. Pedoman interpretasi nilai korelasi (r)

\begin{tabular}{cc}
\hline Interval & Tingkat hubungan \\
\hline $0,00-0,199$ & Sangat rendah \\
$0,20-0,399$ & Rendah \\
$0,40-0,599$ & Sedang \\
$0,60-0,799$ & Kuat \\
$0,80-1,000$ & Sangat Kuat \\
\hline
\end{tabular}

\section{HASIL DAN PEMBAHASAN}

Pengukuran persepsi siswa terhadap pendidikan tinggi menggunakan angket yang tersusun dari 9 butir pernyataan mewakili 3 indikator, yaitu: (1) persepsi tentang pentingnya pendidikan tinggi; (2) persepsi tentang manfaat pendidikan tinggi; dan (3) informasi tentang pendidikan tinggi. Sementara pengukuran persepsi siswa terhadap kecenderungan mereka memilih pendidikan tinggi juga menggunakan angket yang terdiri dari 12 butir pernyataan mewakili 4 indikator, meliputi: (1) adanya keinginan melanjutkan studi ke perguruan tinggi; (2) adanya dorongan untuk melanjutkan studi ke perguruan tinggi; (3) adanya perhatian baik dari diri sendiri maupun keluarga tentang pendidikan tinggi; dan (4) adanya harapan siswa dan atau keluarga terhadap pendidikan tinggi tertentu. Hasil analisis data diuraikan sebagai berikut:

\section{Persepsi tentang pentingnya pendidikan tinggi}

Pada indikator persepsi mengenai pentingnya pendidikan tinggi, persentase siswa menjawab sangat setuju (SS) berjumlah 38,9\%, setuju (S) 55,6\%, tidak setuju (TS) $5,5 \%$, dan tidak satupun responden menjawab sangat tidak setuju (STS) $0 \%$. persentase tersebut dapat dilihat pada diagram pie berikut:

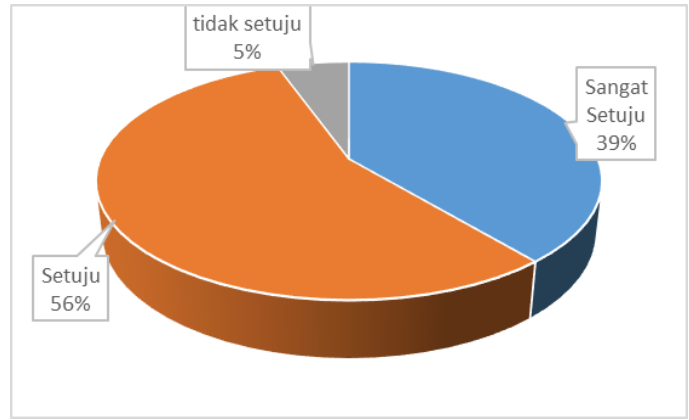

Gambar 1. Diagram pie persentase pilihan jawaban pada indikator pentingnya pendidikan tinggi

Rata-rata persepsi siswa SMA Negeri 1 Blangjerango untuk indikator pentingnya pendidikan tinggi adalah 3,23 dengan angka persentase sebesar $80,64 \%$. Bila dikonsultasikan kepada tabel kriteria penilaian hasil persentase maka indikator ini berada pada kategori "baik". Dari hasil analisis data juga ditemukan bahwa persentase tertinggi terdapat pada butir pernyataan yang menyatakan bahwa pada pendidikan tinggi diajarkan keterampilan hidup (85,3\%). Pada indikator ini juga mengungkap bahwa siswa setuju pendidikan tinggi dapat membangun dan memperluas relasi dan koneksi serta menjadi salah satu prasyarat lapangan pekerjaan $(77,9 \%)$ dan $(78,7 \%)$.

\section{Persepsi tentang manfaat pendidikan tinggi}

Pernyataan yang mewakili indikator persepsi tentang manfaat pendidikan tinggi berjumlah 3 butir dari total 21 butir pernyataan pada angket. Pada indikator ini persentase

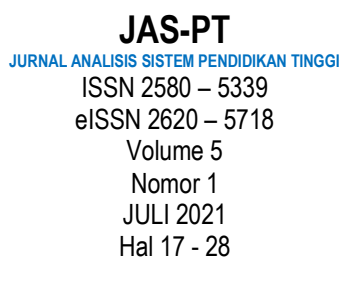

DOSEN INDONESIA SEMESTA 
siswa menjawab sangat setuju (SS) berjumlah $71,2 \%$, setuju (S) $27,9 \%$, tidak setuju (TS) $0 \%$, dan sangat tidak setuju (STS) $0,8 \%$. Persentase tersebut dapat dilihat pada diagram pie berikut:

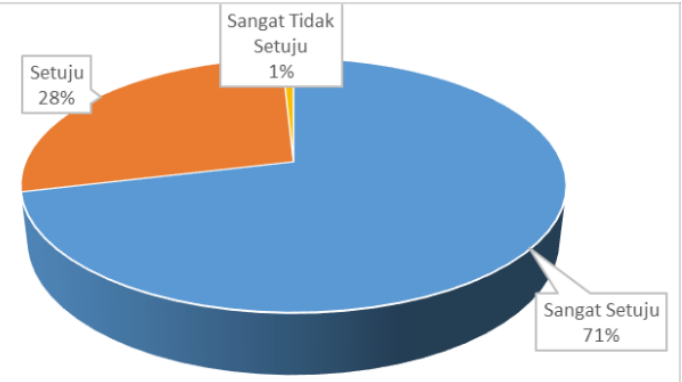

Gambar 2. Diagram pie persentase pilihan jawaban pada indikator manfaat pendidikan tinggi

Rerata persepsi siswa pada indikator manfaat pendidikan tinggi adalah 3,58 dengan angka persentase sebesar $89,5 \%$. Bila merujuk pada tabel kriteria penilaian hasil persentase maka persepsi siswa pada indikator manfaat pendidikan tinggi berada pada kategori "sangat baik". Dari hasil analisis data juga ditemukan bahwa persentase tertinggi terdapat pada butir pernyataan yang menyatakan bahwa pendidikan tinggi memperluas wawasan dan pengetahuan $(93,4 \%)$. Selain itu jawaban responden pada indikator ini juga mengungkap bahwa siswa setuju bahwa pendidikan tinggi mengembangkan ilmu pengetahuan dan mengubah pola pikir dan pola perilaku seseorang menjadi lebih baik $(88,2 \%)$ dan $(86,8 \%)$.

\section{Persepsi tentang informasi mengenai pendidikan tinggi}

Pernyataan yang mengukur persepsi responden pada indikator informasi mengenai pendidikan tinggi berjumlah 3 butir dari total 21 butir pernyataan pada instrumen angket. Pada indikator ini, persentase siswa menjawab sangat setuju (SS) berjumlah 58,76\%, setuju (S) 38,98\%, tidak setuju (TS) 2,26\%, dan tidak satupun siswa menjawab sangat tidak setuju (STS) $0 \%$. Persentase tersebut dapat dilihat pada diagram pie berikut:

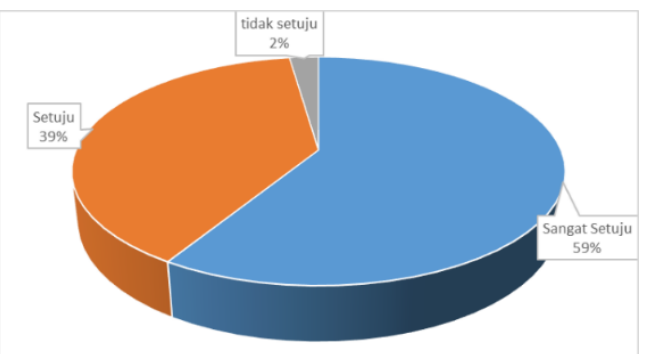

\section{Gambar 3. Diagram pie persentase pilihan jawaban pada indikator informasi tentang} perguruan tinggi.

Rerata indikator persepsi siswa terkait informasi tentang pendidikan tinggi adalah 3,47, dengan angka persentase sebesar $86,76 \%$. Setelah dikonsultasikan kepada tabel kriteria

JAS-PT

JURNAL ANALISIS SISTEM PENDIDIKAN TINGGI ISSN $2580-5339$ eISSN $2620-5718$

Volume 5

Nomor 1

JULI 2021

Hal $17-28$ penilaian hasil persentase maka persepsi siswa pada indikator ini berada pada kategori "sangat baik". Hasil analisis data juga menunjukkan bahwa persentase tertinggi terdapat pada butir pernyataan yang menyatakan bahwa cara mendapatkan informasi mengenai perguruan tinggi adalah dengan bertanya kepada orang yang lebih tahu $(88,2 \%)$, sedangkan butir pernyataan yang menyatakan bahwa dalam memilih perguruan tinggi, penting mengetahui akreditasinya, dan butir pernyataan yang menyatakan dalam 
memilih perguruan tinggi, pertimbangan tentang lingkungan dan fasilitas yang tersedia sangat penting, keduanya memperoleh persentase sama, yakni $86,03 \%$.

\section{Persepsi tentang adanya keinginan melanjutkan studi ke pendidikan tinggi}

Pernyataan yang mewakili indikator adanya keinginan berjumlah 3 butir dari total 21 butir pernyataan pada angket. Pada indikator ini, persentase siswa menjawab sangat setuju (SS) berjumlah $62,7 \%$, setuju (S) $25,7 \%$, tidak setuju (TS) $11,2 \%$, dan sangat tidak setuju (STS) $0,3 \%$. Persentase tersebut dapat dilihat pada diagram pie berikut:

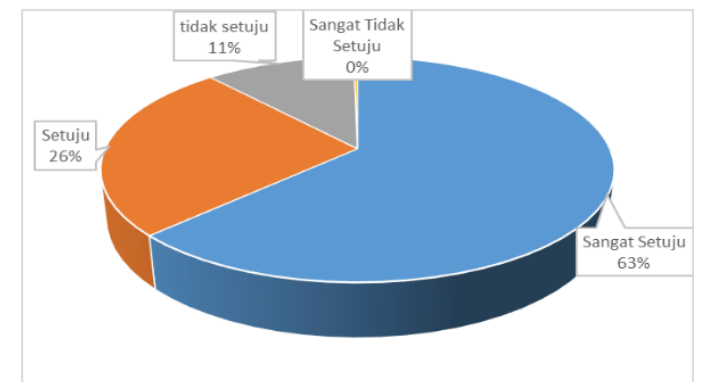

Gambar 4. Diagram pie persentase pilihan jawaban siswa pada indikator adanya keinginan melanjutkan studi ke pendidikan tinggi.

Rerata persepsi siswa pada indikator adanya keinginan untuk melanjutkan studi ke pendidikan tinggi adalah 3,31, dengan angka persentase sebesar $82,8 \%$. Setelah dikonsultasikan kepada tabel kriteria penilaian hasil persentase maka persepsi siswa pada indikator ini berada pada kategori "sangat baik". Dari hasil analisis data juga ditemukan bahwa persentase tertinggi terdapat pada butir pernyataan yang menyatakan bahwa saya memilih pendidikan tinggi yang dapat mewujudkan cita-cita saya $(95,6 \%)$, sedangkan persentase terendah adalah pada butir pernyataan yang menyatakan bahwa saya memilih perguruan tinggi yang memiliki reputasi dan bergengsi $(67,6 \%)$.

\section{Persepsi tentang adanya dorongan untuk melanjutkan studi ke pendidikan tinggi}

Pernyataan yang mewakili indikator persepsi siswa tentang adanya dorongan untuk melanjutkan studi ke pendidikan tinggi berjumlah 3 butir dari total 21 butir pernyataan pada instrumen angket. Pada indikator ini persentase siswa menjawab sangat setuju (SS) berjumlah $48,3 \%$, setuju (S) $43,5 \%$, tidak setuju (TS) 7,9\%, dan sangat tidak setuju (STS) $0,3 \%$. Persentase tersebut dapat dilihat pada diagram pie berikut:

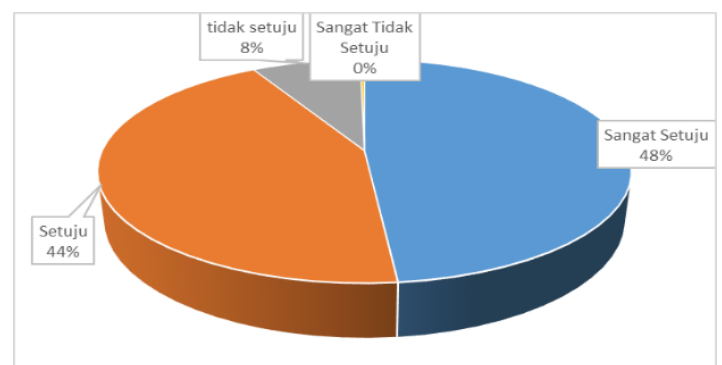

\section{Gambar 5. Diagram pie persentase pilihan jawaban siswa pada indikator adanya dorongan untuk melanjutkan studi ke pendidikan tinggi}

Rerata persepsi siswa pada indikator adanya dorongan untuk melanjutkan studi ke pendidikan tinggi adalah 3,25 , dengan angka persentase sebesar $81,13 \%$. Bila dikonsultasikan kepada tabel kriteria penilaian hasil persentase maka diketahui bahwa persepsi siswa terhadap indikator ini berada pada kategori "sangat baik". Analisis dari data indikator ini juga menemukan bahwa persentase tertinggi terdapat pada butir

JAS-PT
JURNAL ANALISIS SISTEM PENDIDIKAN TINGGI
ISSN $2580-5339$
eISSN 2620 - 5718
Volume 5
Nomor 1
JULI 2021
Hal 17 - 28

DOSEN INDONESIA SEMESTA 
pernyataan yang menyatakan bahwa saya memilih perguruan tinggi sesuai dengan minat dan keterampilan yang saya miliki $(87,5 \%)$. Persentase terendah adalah pada butir pernyataan yang menyatakan bahwa lingkungan sosial menentukan dalam memilih perguruan tinggi $(75,7 \%)$.

\section{Persepsi tentang adanya perhatian untuk melanjutkan studi ke pendidikan tinggi}

Pernyataan yang mewakili indikator persepsi siswa tentang adanya dorongan untuk melanjutkan studi ke pendidikan tinggi berjumlah 3 butir dari total 21 butir pernyataan pada instrumen angket. Pada indikator ini persentase siswa menjawab sangat setuju

(SS) berjumlah 55,8\%, setuju (S) 42,7\%, tidak setuju (TS) 1,1\%, dan sangat tidak setuju (STS) $0,3 \%$. Persentase tersebut dapat dilihat pada diagram pie berikut:

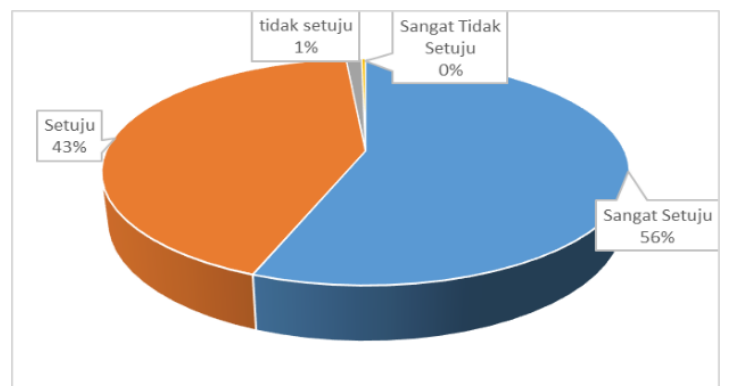

\section{Gambar 6. Diagram pie persentase pilihan jawaban siswa pada indikator adanya perhatian untuk melanjutkan studi ke pendidikan tinggi}

Rerata persepsi siswa pada indikator adanya perhatian untuk melanjutkan studi ke pendidikan tinggi adalah 3,4 , dengan angka persentase sebesar $86,03 \%$. Bila dikonsultasikan menurut tabel kriteria penilaian hasil persentase maka diketahui bahwa persepsi siswa terhadap indikator ini berada pada kategori "sangat baik". Hasil analisis data juga menemukan bahwa persentase tertinggi terdapat pada butir pernyataan yang menyatakan bahwa saya belajar giat agar dapat diterima di perguruan tinggi yang saya pilih $(90,4 \%)$. Persentase terendah adalah pada butir pernyataan yang menyatakan bahwa saya perlu meninjau langsung perguruan tinggi yang akan saya pilih $(78,7 \%)$.

\section{Persepsi tentang adanya harapan pada pendidikan tinggi}

Pernyataan yang mewakili indikator persepsi siswa tentang adanya harapan mereka pada pendidikan tinggi berjumlah 3 butir dari total 21 butir pernyataan pada instrumen angket. Pada indikator ini persentase siswa menjawab sangat setuju (SS) berjumlah $76,6 \%$, setuju (S) 22,3\%, tidak setuju (TS) 1,1\%, dan tidak ada seorang siswapun yang memilih jawaban sangat tidak setuju (STS) $0 \%$. Persentase tersebut dapat dilihat pada diagram pie berikut:

JAS-PT

JURNAL ANALISIS SISTEM PENDIDIKAN TINGGI

ISSN $2580-5339$

elSSN $2620-5718$

Volume 5

Nomor 1

JULI 2021

Hal 17 - 28

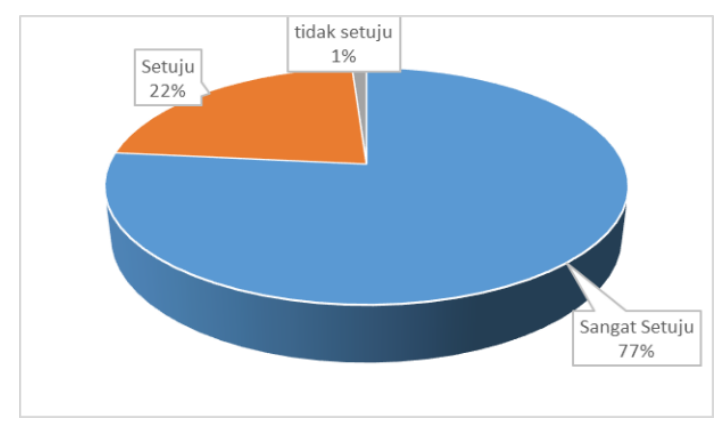

Gambar 7. Diagram pie persentase pilihan jawaban pada indikator adanya harapan siswa pada pendidikan tinggi 
Rerata persepsi siswa pada indikator adanya harapan siswa pada pendidikan tinggi adalah 3,7, dengan angka persentase sebesar 92,2\%. Bila dikonsultasikan pada tabel kriteria penilaian hasil persentase maka diketahui bahwa persepsi siswa terhadap indikator ini berada pada kategori "sangat baik". Analisis dari data indikator ini juga menemukan bahwa persentase tertinggi terdapat pada butir pernyataan yang menyatakan bahwa saya berharap perguruan tinggi yang saya pilih dapat mengantarkan saya menggapai cita-cita (94,9\%). Persentase terendah adalah pada butir pernyataan yang menyatakan bahwa saya berharap perguruan tinggi yang saya pilih membuat saya mendapatkan penghargaan dan kedudukan sosial yang lebih tinggi $(89,7 \%)$. Secara umum responden menunjukkan harapan yang tinggi pada pendidikan tinggi.

\section{Hasil Uji Statistik}

Besarnya nilai korelasi antara persepsi siswa terhadap pendidikan tinggi dan kecenderungan mereka memilih pendidikan tinggi lanjutan dapat dilihat pada Tabel 5 berikut ini.

Tabel 5. Besarnya nilai korelasi antara persepsi siswa terhadap pendidikan tinggi dan kecenderungan mereka memilih pendidikan tinggi

\section{Model Summary}

Model R R Square Adjusted R Square Std. Error of the Estimate

\begin{tabular}{lllll}
\hline 1 & $.520^{\mathrm{a}}$ & .271 & .248 & 3.02614 \\
\hline
\end{tabular}

\section{a. Predictors: (Constant), Persepsi}

Tabel 5 di atas menunjukkan besarnya nilai korelasi $(R)$ yaitu sebesar 0,520, dimana koefisien determinasi ( $R$ square) sebesar 0,271 , yang mengandung pengertian bahwa pengaruh variabel bebas (persepsi terhadap pendidikan tinggi) terhadap variabel terikat (kecenderungan memilih pendidikan tinggi lanjutan) adalah sebesar 27,1\%. Bila merujuk pada tabel pedoman interpretasi nilai korelasi $(R)$, maka tingkat hubungan antara kedua variabel ini berada pada kategori sedang.

Besar $F$ hitung penelitian ini dapat dilihat pada Tabel 6 berikut.

Tabel 6. Besarnya nilai $\mathrm{F}$ hitung

\begin{tabular}{l|r|r|r|c|c} 
Model & Sum of Squares & Df & Mean Square & F & Sig. \\
\hline 1 Regression & 108.842 & 1 & 108.842 & 11.886 & $.002^{\mathrm{b}}$ \\
\hline Residual & 293.040 & 32 & 9.157 & & \\
\hline Total & 401.882 & 33 & & & \\
\hline
\end{tabular}

a. Dependent Variable: Kecenderungan

b. Predictors: (Constant), Persepsi

Tabel 6 di atas memperlihatkan nilai $F$ hitung $=11.886$ dengan tingkat signifikansi sebesar 0,002 <0,05, maka model regresi dapat digunakan untuk memprediksi variabel kecenderungan atau dengan kata lain ada pengaruh variabel persepsi siswa tentang pendidikan tinggi terhadap variabel kecenderungan memilih pendidikan tinggi lanjutan.

Tabel 7.Koefisien regresi

\begin{tabular}{lr|r|r|r|r|} 
& \multicolumn{2}{c}{ Unstandardized Coefficients } & Standardized Coefficients & & \\
Model & $\mathrm{B}$ & Std. Error & Beta & t & Sig. \\
\hline 1 (Constant) & 18.596 & 6.536 & & 2.845 & .008 \\
\hline Persepsi & .729 & .211 & .520 & 3.448 & .002 \\
\hline
\end{tabular}

a. Dependent Variable: Kecenderungan

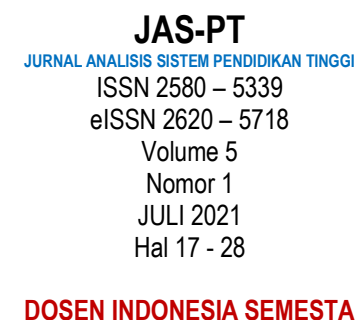

DOSEN INDONESIA SEMESTA 
Tabel 7. di atas meunjukkan bahwa nilai konstan (a) sebesar 18,596, sedangkan nilai persepsi terhadap pendidikan tinggi (b/ koefisien regresi) sebesar 0,729 , sehingga persamaan regresi dapat ditulis: $Y=a+b X=18,596+0,729 X$

Koefisien regresi $X$ sebesar 0,729 menyatakan bahwa setiap penambahan $1 \%$ nilai Persepsi terhadap pendidikan tinggi, maka nilai kecenderungan memilih pendidikan tinggi lanjutan bertambah sebesar 0,729 . Koefisien regresi tersebut bernilai positif. Sehingga dapat dikatakan bahwa arah pengaruh variabel $X$ terhadap $Y$ adalah positif.

Meskipun hasil penelitian menunjukkan bahwa persepsi siswa terhadap perguruan tinggi sangat baik, namun data pihak sekolah menerangkan bahwa dari tahun ke tahun jumlah siswa yang melanjutkan studi ke perguruan tinggi hanya di bawah $50 \%$. Hal tersebut semakin memperkuat dugaan penulis bahwa faktor utama dari rendahnya persentase siswa yang melanjutkan studi ke perguruan tinggi adalah faktor ekonomi keluarga. Dalam pemilihan perguruan tinggi, faktor status program studi dan biaya perkuliahan selalu menjadi perhatian utama calon mahasiswa (Deni, 2016; Riko, 2015). Siswa yang memberikan persepsi sangat baik, tidak serta merta memiliki minat yang sangat tinggi pula, beberapa penelitian sebelumnya juga mendapati hal demikian.

Selain itu, instrumen angket yang digunakan juga memiliki sejumlah kelemahan, sekalipun angket tersebut sudah disusun secara baik. Responden sering tidak teliti dalam menjawab, sehingga ada pertanyaan yang terlewati tidak dijawab, atau jawaban yang asal-asalan dari sejumlah siswa. Adapula responden yang tidak jujur dalam menjawab pertanyaan pada angket sehingga hal tersebut memungkinkan hasil yang berbeda dari suatu pengukuran (Arikunto, 2006). Faktor lain yang memiliki andil pada rendahnya persentase siswa yang melanjutkan studi ke perguruan tinggi adalah faktor sosial budaya, seperti pernikahan di usia muda yang mengharuskan mereka bekerja untuk memenuhi kebutuhan keluarga dan terpaksa menyudahi kewajibannya menuntut ilmu pengetahuan ke jenjang yang lebih tinggi.

\section{SIMPULAN DAN SARAN}

Hasil penelitian menunjukkan bahwa secara umum persepsi siswa SMA Negeri 1 Blangjerango terhadap pendidikan tinggi dan kecenderungan mereka dalam memilih pendidikan tinggi lanjutan berada pada kategori sangat baik (85,57\%). Faktor ekonomi keluarga menjadi faktor utama rendahnya persentase lulusan SMA tersebut melanjutkan studi ke perguruan tinggi. Pengaruh variabel bebas (persepsi terhadap pendidikan tinggi) terhadap variabel terikat (kecenderungan memilih pendidikan tinggi lanjutan) adalah sebesar $27,1 \%$. Bila merujuk pada tabel pedoman interpretasi nilai korelasi, maka tingkat hubungan antara kedua variabel ini berada pada kategori sedang. Ada pengaruh variabel persepsi siswa tentang pendidikan tinggi terhadap variabel kecenderungan memilih pendidikan tinggi lanjutan. Arah pengaruh variabel bebas terhadap variabel terikat pada penelitian ini adalah positif. Pihak sekolah dapat terus meningkatkan layanan bimbingan dan konseling di sekolah, khususnya layanan yang memberikan informasi kepada siswa terkait pendidikan tinggi lanjutan. Selain itu perlu dilakukan penelitian lanjutan untuk melihat persepsi siswa terhadap pendidikan tinggi di sekolah-sekolah lainnya.

JAS-PT

JURNAL ANALISIS SISTEM PENDIDIKAN TINGG

ISSN $2580-5339$

eISSN $2620-5718$

Volume 5

Nomor 1

JULI 2021

Hal $17-28$

\section{DAFTAR PUSTAKA}

Arikunto, S. (2006). Prosedur Penelitian Suatu Pendekatan Praktik. Jakarta: Rineka Cipta. 
Deni, Gustian. (2016). Persepsi Masyarakat Terhadap Pendidikan Perguruan Tinggi. (Studi Deskriptif tentang Kurangnya Minat Pendidikan ke Jenjang Perguruan Tinggi pada Peuda dan Pemudi Kampung Pungkur Loji Desa Cicalengka Kulon Kecamatan Cicalengka Kabupaten Bandung). Skripsi. UIN Bandung.

Hidayat, W. (2016). Persepsi Siswa SMA Kota Parepare Tentang Stain Parepare. KURIOSITAS: Media Komunikasi Sosial dan Keagamaan, 9(1), pp.49-56.

Irnawati, I., 2019. PERSEPSI SISWA TERHADAP PENDIDIKAN TINGGI DAN KECENDERUNGANNYA MEMILIH PENDIDIKAN TINGGI LANJUTAN (STUDI PADA SISWA KELAS XII SMA NEGERI 3 LUWU TAHUN AJARAN 2017/2018) (Doctoral dissertation, Universitas Negeri Makassar).

Mashadi, M. (2019). TINJAUAN PERMENPAR NO. 28-2015 USAHA PENJUALAN MAKANAN PADA SKALA MIKRO KECIL SURYA KENCANA BOGOR. IKRA-ITH EKONOMIKA, 2(3), 148-156.

Mulyana, M. (2012). Consumer Behaviour: Sukses Dengan Memahami Konsumen.

Mustika, A., Linda, D.R.B., \& Irfal. (2019). Persepsi Siswa Terhadap Minat Kuliah Di Perguruan Tinggi Pariwisata. MPU PROCURATIO, 1 (1 April), pp.68-73.

Neva, S., \& Amyar, F. (2021). Pengaruh Fraud Diamond dan Gonetheory Terhadap Academic Fraud. JAS-PT (Jurnal Analisis Sistem Pendidikan Tinggi Indonesia), 5(1), 41-50.

Nurhaedah \& Anas A. (2012). Hubungan Antara Minat dan Persepsi Lulusan SMU Terhadap Program Studi Pendidikan Guru Sekolah Dasar (PGSD). Laporan Penelitian: Jurusan PGSD FIP UN dan Jurusan PTSP FT UNM.

Nurachmad, E., \& Sukamto, A. (2020). Pelatihan Persiapan Studi Lanjut Di Jurusan Teknologi Informasi. Jurnal Abdimas, 4(1), 61-70.

Pramiudi, U. \& Setiawan B. (2019). Penelusuran Persepsi Mahasiswa Atas Program Studi Akuntansi dan Minat Studi Lanjut. JAS-PT (Jurnal Analisis Sistem Pendidikan Tinggi Indonesia), 2(2), pp.103-113.

Purba, J. H. V. (2005). Strategi Diversifikasi Produk Terhadap Tingkat Omzet Penjualan (Studi Kasus pada PT. Surya Pelita Pratama). Jurnal Ilmiah Ranggagading, 5(1), 59-66.

Riduwan. (2004). Belajar Mudah Penelitian untuk Guru-Karyawan dan Pemula. Bandung: Alfabeta.

Riko, M. (2015). Persepsi Siswa 4 SMA terhadap 2 Sekolah Tinggi Ekonomi dan Fakultas Ekonomi di Kota Jambi. Jurnal Ilmiah Universitas Batanghari Jambi, 15(3).

Riwoe, F. L. R., \& Purba, J. H. V. (2021). Analisis Sikap Multiatribut Fishbein Dalam Pengambilan Keputusan Mahasiswa Memilih Kampus IBI Kesatuan. JAS-PT (Jurnal Analisis Sistem Pendidikan Tinggi Indonesia), 5(1), 51-60.

Riwoe, F. L. R., \& Mulyana, M. (2020). Model Struktural Kepuasan Mahasiswa Dengan Kualitas Pelayanan Sebagai Variabel Eksogen. Jurnal IImiah Manajemen Kesatuan, 8(1), 1-8.

Sari, N. \& lqbal, M. (2021). PERSEPSI SISWA DIFABEL TERHADAP KELANJUTAN STUDI DI PERGURUAN TINGGI. Genta Mulia: Jurnal IImiah Pendidikan, 12(1).

Sugiyono. (2010). Statistika untuk Penelitian. Bandung: Alfabe.

(2013). Metode Penelitian Kuantitatif Kualitatif R\&D. Bandung: $\quad$ Alfabeta.

JAS-PT

JURNAL ANALISIS SISTEM PENDIDIKAN TINGG ISSN $2580-5339$ eISSN $2620-5718$

Volume 5

Nomor 1

JULI 2021

Hal $17-28$ 
Supriatna, S., Mulyana, M., \& Utari, W. D. (2021). Evaluasi Kelompok Referensi Yang Mempengaruhi Keputusan Pembelian Konsumen Foresthree Coffee. Jurnal IImiah Pariwisata Kesatuan, 2(2), 1-10.

Triyono, T. \& Febriani, R.D. (2018). Persepsi Peserta Didik Sekolah Menengah Atas Terhadap Pendidikan Lanjutan. Edudikara: Jurnal Pendidikan Dan Pembelajaran, 3(1), pp.70-77.

Widarta, F. O. (2020). Persepsi Siswa Terhadap Keterampilan Dasar Mengajar Mahasiswa Program PLP II Program Studi Pendidikan Biologi PSDKU Universitas Syiah Kuala Gayo Lues di SMP Negeri 1 Blangjerango. BIOTIK: Jurnal IImiah Biologi Teknologi dan Kependidikan, 8(1), 106-118.

https://o.id/publication.html?aceh.bps.gPublikasi\%5BtahunJudul\%5D=\&PublPubli\%5Bk ataKunci\%5D=aceh+dalam+angka\&Publikasi. diakses pada 4 Maret 2021.

Hal 17 - 28

DOSEN INDONESIA SEMESTA 